УДК 658.8.013-052

JEL Classification: M31

КОНОВАЛЕНКО А. С. ${ }^{1}$

\title{
АНАЛІЗ ВПЛИВУ СОЦІАЛЬНОГО ОТОЧЕННЯ НА МОДЕЛЬ ПОВЕДІНКИ СПОЖИВАЧА
}

DOI: $10.32620 /$ cher.2020.4.10

Постановка проблеми. У статті наведено авторський підхід до аналізу впливу соціального оточення на модель поведінки споживача, який передбачає визначення інтенсивності та направленості впливу груп соціального оточення на основі оцінки якості референтного простору шляхом застосування запропонованої моделі CNSA («Критика-шум-тиша-порада»). Метою статті є визначення методичних підходів до аналізу впливу соціального оточення у процесі прийняття рішення про придбання та споживання продуктів харчування дітьми шкільного віку. Методологічною основою дослідження стали напрацювання вітчизняних та зарубіжних учених з питань проведення маркетингових досліджень. Основною гіпотезою дослідження стало припущення щодо необхідності обгрунтування методичних підходів до аналізу впливу соціального оточення на поведінку споживача із урахуванням інтенсивності та направленості впливу різних груп. Виклад основного матеріалу. Запропонована у статті методика аналізу впливу соціального оточення на поведінку споживача передбачає визначення інтенсивності впливу груп соціального оточення, як ваги сприйняття респондентами значення впливу цієї групи, та здійснення оцінки направленості впливу соціального оточення через аналіз якості референтного простору на основі розробленої моделі CNSA («Критикашум-тиша-порада»). На основі отриманих даних можливо відтворити референтний простір респондента, який є характеристикою якості впливу соціального оточення на респондентів в розрізі конкретної проблематики. На основі запропонованої методики здійснено аналіз впливу соціального оточення на споживчу поведінку дітей шкільного віку. Отримані дані характеризують референтний простір дітей $з$ огляду на обговорення тематики системи харчування дітей шкільного віку. Орихінальність та практична значущість дослідження. Наведена методика має теоретичну та прикладну значущість та може бути використана для оцінки впливу соціального оточення для різних груп респондентів із питань конкретної проблематики поведінки споживача. Висновки. Обгрунтовано методику та на їі основі здійснено аналіз впливу соціального оточення на модель споживчої поведінки дітей шкільного віку на ринку продуктів та послуг харчування. Перспективи подальших досліджень спрямовані на визначення характеру впливу спонукальних та внутрішніх чинників на поведінку споживача, визначення особливостей процесу прийняття рішення дітьми шкільного віку щодо придбання та споживання продуктів харчування.

\section{Ключові слова:}

поведінка споживача, соціальне оточення, референтний простір, модель споживчої поведінки, модель CNSA

\section{ANALYSIS OF THE SOCIAL ENVIRONMENT INFLUENCE ON THE CONSUMER BEHAVIOR MODEL}

Formulation of the problem. The author's approach to the analysis of the impact of the social environment on the model of consumer behavior, which involves determining the intensity and direction of the impact of social groups based on the quality of the reference space by applying the proposed CNSA model ("Criticism-noise-silence-advice"). The aim of the research is to determine the methodological approaches to the analysis of the impact of the social environment in the decision-making process on the purchase and consumption of food by school-age children. The methodological basis of the study was the work of ukrainian and foreign scientists on marketing research. The hypothesis of the resaerch was the assumption of the

Коноваленко Анастасія Сергіївна, канд. екон. наук, доцент, доцент кафедри маркетингу, Таврійський державний агротехнологічний університет імені Дмитра Моторного, м. Мелитополь, Україна.

Konovalenko Anastasiia, Ph.D in Economics, Associate professor of the Marketing Department, D. Motornyi Tavria State Agrotechnological University, Melitopol, Ukraine.

ORCID ID: 0000-0001-9061-5989

e-mail: anastasiia.konovalenko@tsatu.edu.ua 
need to substantiate methodological approaches to the analysis of the impact of the social environment on consumer behavior, taking into account the intensity and direction of the impact of different groups. The statement of basic materials. The method of analysis of the influence of social environment on consumer behavior proposed in the article involves determining the intensity of influence of social environment groups as the weight of respondents' perception of the importance of this group, and assessing the direction of social environment through analysis of the quality of the reference space based on the developed CNSA model ("Criticism-noise-silence-advice"). Based on the obtained data, it is possible to reproduce the reference space of the respondent, which is a characteristic of the quality of the impact of the social environment on the respondents in terms of specific issues. Based on the proposed method, the analysis of the impact of the social environment on the consumer behavior of school-age children. The obtained data characterize the reference space of children in view of the discussion of the nutrition system of school-age children. The originality and practical significance of the research. This technique has theoretical and applied significance and can be used to assess the impact of the social environment for different groups of respondents on specific issues of consumer behavior. Conclusions. The methodology is substantiated and on its basis the analysis of the influence of the social environment on the model of consumer behavior of school-age children in the market of food products and services is carried out. Perspectives of further research will be aimed at determining the nature of the influence of motivating and internal factors on consumer behavior, determining the specifics of the decision-making process of school-age children on the purchase and consumption of food.

Key words:

consumer behavior, social environment, reference space, consumer behavior model, CNSA model.

\section{АНАЛИЗ ВЛИЯНИЯ СОЦИАЛЬНОГО ОКРУЖЕНИЯ НА МОДЕЛЬ ПОВЕДЕНИЯ ПОТРЕБИТЕЛЯ}

Постановка проблемы. В статье приведен авторский подход к анализу влияния социального окружения на модель поведения потребителя, который предусматривает определение интенсивности и направленности влияния групп социального окружения на основе оценки качества референтного пространства путем применения предложенной модели CNSA («Критика-шум-тишина-совет»). Целью статьи является определение методических подходов к анализу влияния социального окружения в процессе принятия решения о покупке и потребление продуктов питания детьми школьного возраста. Методологической основой исследования стали наработки отечественных и зарубежных ученых по вопросам проведения маркетинговых исследований. Основной гипотезой исследования стало предположение о необходимости обоснования методических подходов к анализу влияния социального окружения на поведение потребителя с учетом интенсивности и направленности влияния различных групп. Изложение основного материала. Предложенная в статье методика анализа влияния социального окружения на поведение потребителя предполагает определение интенсивности влияния групп социального окружения, как веса восприятия респондентами значения воздействия этой группы, и осуществления оценки направленности влияния социального окружения путем анализа качества референтного пространства на основе разработанной модели CNSA («Критика-шумтишина-совет»). На основе полученных данных возможно воспроизвести референтное пространство респондента, которое является характеристикой качества влияния социального окружения на респондентов в разрезе конкретной проблематике. На основе предложенной методики проведен анализ влияния социального окружения на потребительское поведение детей школьного возраста. Полученные данные характеризуют референтное пространство детей с учетом обсуждения тематики системы питания детей школьного возраста. Оригинальность и практическая значимость исследования. Приведенная методика имеет теоретическое и прикладное значение, может быть использована для оценки влияния социального окружения для различных групп респондентов по вопросам конкретной проблематике поведения потребителя. Выводы. Обоснована методика и на ее основе осуществлен анализ влияния социального окружения на модель потребительского поведения детей школьного возраста на рынке продуктов и услуг питания. Перспективы дальнейших исследований направлены на определение характера влияния побудительных факторов и внутренних мотивов на поведение потребителя, определение особенностей процесса принятия детьми школьного возраста решения о покупке и потребления продуктов питания.

\section{Ключевые слова:}

поведение потребителя, социальное окружение, референтное пространство, модель поведения потребителя, модель CNSA. 
Постановка проблеми. В процесі дорослішання та споживчої соціалізації діти шкільного віку стикаються із необхідністю приймати самостійні рішення щодо вибору продуктів та послуг харчування. Відсутність сталої моделі споживчої поведінки дітей обумовлює підвищення вразливості даної категорії споживачів перед впливом спонукальних чинників та залежність дітей у своєму виборі від інформації, думок, харчових стереотипів, що складається під впливом соціального оточення. Розуміння характеру впливу соціального оточення на споживчу поведінку дітей шкільного віку на ринку продуктів та послуг харчування дозволить формувати ефективний маркетинговий механізм управління безпекою їх харчування на основі застосування науково-обгрунтованих даних щодо можливостей здійснення керованого впливу на формування мотиваційного поля дітей.

Аналіз останніх досліджень i публікацій. Теоретичні основи вивчення поведінки споживачів закладені у наукових роботах таких дослідників, як Блекуелл Р.Д., Говард Дж., Енджел Дж.Ф., Коллат Д.Т., Ламбен Ж.-Ж., Мініард П., Роджерс Е., Фішбейн М., Шет Дж., які сформували підходи до визначення чинників, що впливають на поведінку споживача, етапи процесу прийняття рішення про купівлю та споживання продуктів харчування, підходи до дослідження поведінкової реакції споживача на маркетинговий вплив з боку суб'єктів господарювання тощо. Окремі аспекти вивчення мотивації споживачів розкриті у роботах таких іноземних і вітчизняних учених, як Бернс Р.Ф., Буш Л.С., Голубков Є.П., Малхотра Н.К., Старостіна А.О., Черчілль Г.А. та інших.

Проблематика врахування виробниками ключових зарактеристик споживача на ринку продуктів харчування у дитячому сегменті $є$ предметом дослідження Легези Д.Г., Куліш Т.В. Підходи до вивчення мотиваційних характеристик підліткової аудиторії українських споживачів сформовані у роботах Кочкіної Н. Проте, незважаючи на значну велику кількість досліджень поведінки окремих груп споживачів, формування методики та вивчення характеру впливу соціальних чинників на споживчу поведінку дітей шкільного віку залишилась практично поза увагою науковців та потребує біль глибоких досліджень.
Метою статті $\epsilon$ визначення методичних підходів до аналізу впливу соціального оточення у процесі прийняття рішення про придбання та споживання продуктів харчування дітьми шкільного віку.

Виклад основного матеріалу дослідження. Аналіз впливу соціальних чинників спрямований на визначення характеру та сили впливу на дитини референтних груп, груп членства, родини, оточення, кола спілкування, лідерів думок, впливових осіб тощо [1]. 3 метою отримання інформації 3 цього приводу було проведене вибіркове разове опитування дітей шкільного віку шляхом самостійного заповнення респондентами розробленої форми анкети. Такий метод збору інформації дозволяе уникнути здійснення впливу на респондента, що підвищує рівень об'єктивності отриманих даних.

В анкеті було передбачено питання для визначення таких характеристик:

- кола осіб, що впливають на вибір продуктів харчування дитиною;

- сили цього впливу;

- характеру висловлювань оточення щодо систем харчування дитини (критика або рекомендації) та значущості цих висловлювань для дитини;

- визначення кола осіб, з якими дитина спілкується на тему здорового харчування, та регулярність спілкування на цю тему.

На сьогоднішній день відсутній методичний апарат для визначення впливу соціального оточення на споживчий вибір. 3 метою визначення сили та характеру впливу соціального оточення в анкеті передбачено оцінка дитиною сили впливу таких референтних груп:

- родина (батьки, інші родичі);

- однолітки 3 кола спілкування (друзі, однокласники);

- впливові особи (вчителі у школі, тренери, керівники секцій);

- працівників закладів харчування (кафе, магазинів, шкільної їдальні).

Аналіз зовнішніх соціальних чинників, що впливають на модель споживчої поведінки споживача, передбачає визначення чинників, які не мають значення для респондентів, мають важливе значення або $\epsilon$ вирішальним фактором при виборі продукту або послуги [2]. 3 метою визначення значущості груп чинників запропоновано використовувати структуру вихідних даних, наведену у табл. 1. 
Т а б ли ц я 1

Вихідні дані для розрахунку значущості чинників соціального оточення

\begin{tabular}{|l|c|c|c|c|}
\hline \multirow{2}{*}{$\begin{array}{l}\text { Чинники соціаль- } \\
\text { ного оточення }(i)\end{array}$} & $\begin{array}{c}\text { Не мають } \\
\text { значення (1) }\end{array}$ & Важливе (2) & $\ldots$ & $\begin{array}{c}\text { Маютка відповішаль- } \\
\text { не значення (j) }\end{array}$ \\
\hline Група (1) & $Q_{11}$ & $Q_{12}$ & & $Q_{1 j}$ \\
\hline Група (2) & $Q_{21}$ & $Q_{22}$ & & $Q_{2 j}$ \\
\hline$\ldots$ & & & & $Q_{i j}$ \\
\hline Група $(i)$ & $Q_{i 1}$ & $Q_{i 2}$ & & \\
\hline \multicolumn{5}{|c|}{ Джерело: розроблено автором } \\
\hline
\end{tabular}

Пропонується підхід до визначення узагальнюючого показника значущості чинника за наведеною формулою:

$$
W_{i}=\frac{\sum_{n=1}^{j} Q_{i n} *(n-1)}{n-1},
$$

де $W_{i}-$ значущість $i$-го чинника;

$i$ - кількість чинників.

$j$ - кількість варіантів оцінки значущості чинника;
$Q_{i}$ - частка оцінок $i$-го чинника у загальній кількості його оцінок.

В разі, якщо усі респонденти оцінюють окремий чинник як такий, що «не має значення», то за розрахунками значущість даного чинника дорівнюватиме 0. Якщо ж 100\% респондентів вважають даний чинник вирішальним, то значущість чинника дорівнюватиме $100 \%$ (або 1,0) (рис. 1)
0

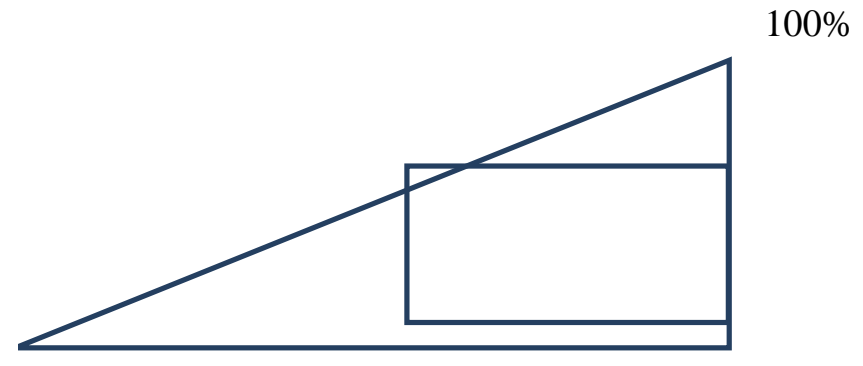

Не має значення

Важливий фактор

Вирішальний фактор

Рисунок 1 - Підхід до визначення значущості чинника Джерело: розроблено автором

Після проведених розрахунків отримано результати, які свідчать про те, що гендерна приналежність не впливає на сприйняття дитиною впливу чинників соціального оточення на іiї споживчий вибір, однак, спостерігається зміна значущості чинників соціального оточення у процесі дорослішання дитини (табл. 2).

Інтенсивність впливу груп соціального оточення визначатиметься, як вага сприйнят- тя дітьми значення впливу цієї групи. Результати ранжування дозволяють визначити групи, думку яких дитини сприймає, як більш або менш авторитетною. Сприйняття дітьми впливу різних груп з соціального оточення свідчить про те, що найбільший вплив на вибір дитиною продуктів харчування мають батьки та інші члени родини (табл. 3).

\section{Вага інтенсивності впливу соціального оточення на} дітей шкільного віку у питаннях харчування

\begin{tabular}{|l|c|c|c|c|}
\hline \multicolumn{1}{|c|}{ Група соціального оточення } & Жіноча стать & Ранг & Чоловіча стать & Ранг \\
\hline Родина & 0,47 & 1 & 0,45 & 1 \\
\hline Однолітки & 0,25 & 2 & 0,26 & 2 \\
\hline Впливові особи & 0,19 & 3 & 0,20 & 3 \\
\hline Персонал закладів & 0,09 & 4 & 0,09 & 4 \\
\hline
\end{tabular}

Т а б л и ц я 3 
Значущість впливу груп соціального оточення на споживчий вибір

Т а б ли ц я 2

дитиною продуктів та послуг харчування

\begin{tabular}{|c|c|c|c|c|}
\hline \multirow{3}{*}{$\begin{array}{c}\text { Вік } \\
\text { дитини } \\
\end{array}$} & \multirow{2}{*}{\multicolumn{4}{|c|}{ Групи соціального оточення }} \\
\hline & & & & \\
\hline & Родина & Однолітки & Впливові особи & Персонал закладів \\
\hline \multicolumn{5}{|c|}{ Жіноча стать } \\
\hline 7 & 0,57 & 0,22 & 0,19 & 0,03 \\
\hline 8 & 0,51 & 0,25 & 0,19 & 0,06 \\
\hline 9 & 0,53 & 0,22 & 0,17 & 0,08 \\
\hline 10 & 0,52 & 0,22 & 0,17 & 0,09 \\
\hline 11 & 0,46 & 0,22 & 0,20 & 0,12 \\
\hline 12 & 0,45 & 0,24 & 0,21 & 0,10 \\
\hline 13 & 0,44 & 0,26 & 0,19 & 0,11 \\
\hline 14 & 0,43 & 0,30 & 0,17 & 0,10 \\
\hline 15 & 0,45 & 0,27 & 0,16 & 0,12 \\
\hline 16 & 0,40 & 0,32 & 0,15 & 0,13 \\
\hline 17 & 0,37 & 0,32 & 0,17 & 0,14 \\
\hline Разом & 0,47 & 0,25 & 0,19 & 0,09 \\
\hline \multicolumn{5}{|c|}{ Чоловіча стать } \\
\hline 7 & 0,54 & 0,21 & 0,19 & 0,06 \\
\hline 8 & 0,51 & 0,20 & 0,21 & 0,08 \\
\hline 9 & 0,51 & 0,24 & 0,20 & 0,06 \\
\hline 10 & 0,48 & 0,21 & 0,24 & 0,07 \\
\hline 11 & 0,47 & 0,27 & 0,19 & 0,07 \\
\hline 12 & 0,48 & 0,22 & 0,21 & 0,08 \\
\hline 13 & 0,45 & 0,26 & 0,21 & 0,08 \\
\hline 14 & 0,45 & 0,27 & 0,18 & 0,09 \\
\hline 15 & 0,36 & 0,27 & 0,23 & 0,14 \\
\hline 16 & 0,34 & 0,29 & 0,25 & 0,13 \\
\hline 17 & 0,28 & 0,33 & 0,21 & 0,17 \\
\hline Разом & 0,45 & 0,26 & 0,20 & 0,09 \\
\hline Загалом & 0,46 & 0,26 & 0,20 & 0,09 \\
\hline
\end{tabular}

Джерело: розроблено автором

Науковці зазначають, що найважливішими є два види референтних груп:

- групи, що задають норми та приклад споживчої поведінки;

- групи, які здійснюють прямий вплив на споживчий вибір серед однієї групи товарів [3].

Прокопенко О.В. та Троян М.Ю. зазначають важливість інформаційних референтних груп, які є групами людей, яким довіряє споживач. У такому випадку вони пропонують розрізнять такі джерела, як «експерти», «зірки», «лідери думок» [4]. Отже, тренери спортивних секцій, які мають давати рекомендації щодо вжитку тих чи інших продуктів харчування 3 огляду на збереження спортивної форми, шкільні вчителі, працівники їдальнь, у більшості випадків не сприймаються дітьми, як експерти у питаннях правильного та безпечного харчування.

Попередні дослідження підтверджують точку зору, що рівень довіри тинейджерів до дорослих майже вдвічі менша за довіру до однолітків. За за результатами досліджень «Teenage Research Unlimited», більш значний рівень авторитету підлітків має матір (89\% опитаних), у той час батькові довіряє лише $61 \%$ підлітків. Для порівняння - у країнах Свропи і США батьки мають практично однаковий авторитет серед підлітків) [5].

Окрім значущості та інтенсивності впливу важливо оцінити й направленість впливу оточення. Досі відсутні методичні підходи до його визначення, тому пропонується характер впливу соціального оточення розглядати через якість спілкування дитини 3 різними референтними групами: що отримує дитина через спілкування на тему харчування, а також чи відбувається обговорення теми харчування з тією чи іншою групою взагалі.

3 цією метою пропонується оцінка якості референтного простору дитини на основі розробленої моделі CNSA («Критика- 
шум-тиша-порада»), яка передбачає розмежування чотирьох типів впливу:

- Criticism («критика») -3 боку оточення дитина чує критику свого вибору продуктів харчування та власних харчових уподобань;

- Noise («шум») - оточення дає поради, які для дитини не мають значення, вона їх не сприймає або вважає зайвими та даремними;

- Silence («тиша») - питання, пов'язані iз харчуванням дитини, не обговорюються 3 певною групою соціального оточення;

- Advice («порада») - дитина отримує поради та рекомендації, які сприймає позитивно, вважає їх цінними та важливими.

Уперше поняття референтної групи ввів Г.Хаймон, який стверджував, що референтною групою $є$ група осіб, з якими людина порівнює власну поведінку, рішення, думку, особистий статус [6]. Тобто, референтні групи дітей шкільного віку - це групи осіб, які при особистому контакті або опосередковано впливають на споживчу поведінку дітей.

Ідеальна референтна група - це група, на думку якої дитина орієнтується у важливих для неї питаннях, подіях. 3 огляду на аналіз впливу соціального оточення на дітей шкільного віку у питаннях їх харчування та харчових уподобань, ідеальна референтна група формує простір порад, які мають значення та важливі, на думку дитини, тож відносяться до сектору А (advice - «порада») Аналіз інтенсивності та направленості впливу різних груп соціального оточення дозволять сформувати кільцеву діаграму, яка відтворює референтний простір дитини, та визначити наявність чи відсутність ідеальної референтної групи. Відсотковий розподіл висловлювань окремих груп соціального оточення за 4 типами впливу дозволить наочно оцінити якість соціального оточення 3 конкретних питань. У даному випадку розглянуто референтний простір дітей з огляду на обговорення тематики системи харчування дітей шкільного віку.

Результати оцінки інтенсивності та направленості впливу соціального оточення за розробленою моделлю CNSA дозволяє визначити якість референтного простору дитини (табл. 4), що надає вичерпну інформацію щодо характеру впливу соціального оточення на формування референтними групами інформаційного простору дитини шкільного віку з огляду на безпеку ії харчування.

Т а б ли ц я 4

Направленість впливу соціального оточення на дітей шкільного віку $з$ питань харчування дітей за моделлю CNSA

\begin{tabular}{|c|c|c|c|c|}
\hline \multirow[b]{2}{*}{ Референтна група } & \multirow{2}{*}{$\begin{array}{c}\text { Характер вислов- } \\
\text { лювань }\end{array}$} & \multicolumn{2}{|c|}{ Стать дитини } & \multirow[b]{2}{*}{ Загалом } \\
\hline & & Жіноча & Чоловіча & \\
\hline \multirow{4}{*}{ Родина } & Критика (C) & 16,7 & 17,38 & 17,06 \\
\hline & Шум (N) & 22,2 & 23,57 & 22,91 \\
\hline & Тиша (S) & 27,5 & 26,43 & 26,97 \\
\hline & Порада (A) & 33,5 & 32,62 & 33,05 \\
\hline \multirow{4}{*}{ Однолітки } & Критика (C) & 6,7 & 9,76 & 8,23 \\
\hline & Шум (N) & 33,3 & 32,86 & 33,05 \\
\hline & Тиша (S) & 50,5 & 48,57 & 49,52 \\
\hline & Порада (А) & 9,6 & 8,81 & 9,19 \\
\hline \multirow{4}{*}{ Впливові особи } & Критика (C) & 7,7 & 8,81 & 8,23 \\
\hline & Шум (N) & 25,8 & 22,62 & 24,22 \\
\hline & Тиша (S) & 51,9 & 52,62 & 52,27 \\
\hline & Порада (А) & 14,6 & 15,95 & 15,27 \\
\hline \multirow{4}{*}{ Працівники } & Критика (C) & 2,9 & 3,33 & 3,1 \\
\hline & Шум (N) & 37,3 & 30,95 & 34,13 \\
\hline & Тиша (S) & 56 & 60,48 & 58,23 \\
\hline & Порада (А) & 3,8 & 5,24 & 4,53 \\
\hline
\end{tabular}


У графічній інтерпретації доцільно використати кільцеву діаграму, кільця якої розташовують за принципом поступового віддалення від центру фігури за ступенем зменшення значущості впливу. Таким чином може бути сформоване наочне уявлення про якість референтного простору дітей шкільного віку з огляду на питання безпеки ïx харчування. Слід зазначити наявну відмінність якості референтного простору дітей шкільного віку жіночої та чоловічої статі. Дівчата частіше, ніж хлопці, відчувають «шум» в оточенні, референтний простір хлопців характеризується більшою часткою «критики», ніж простір дівчат (рис. 2).

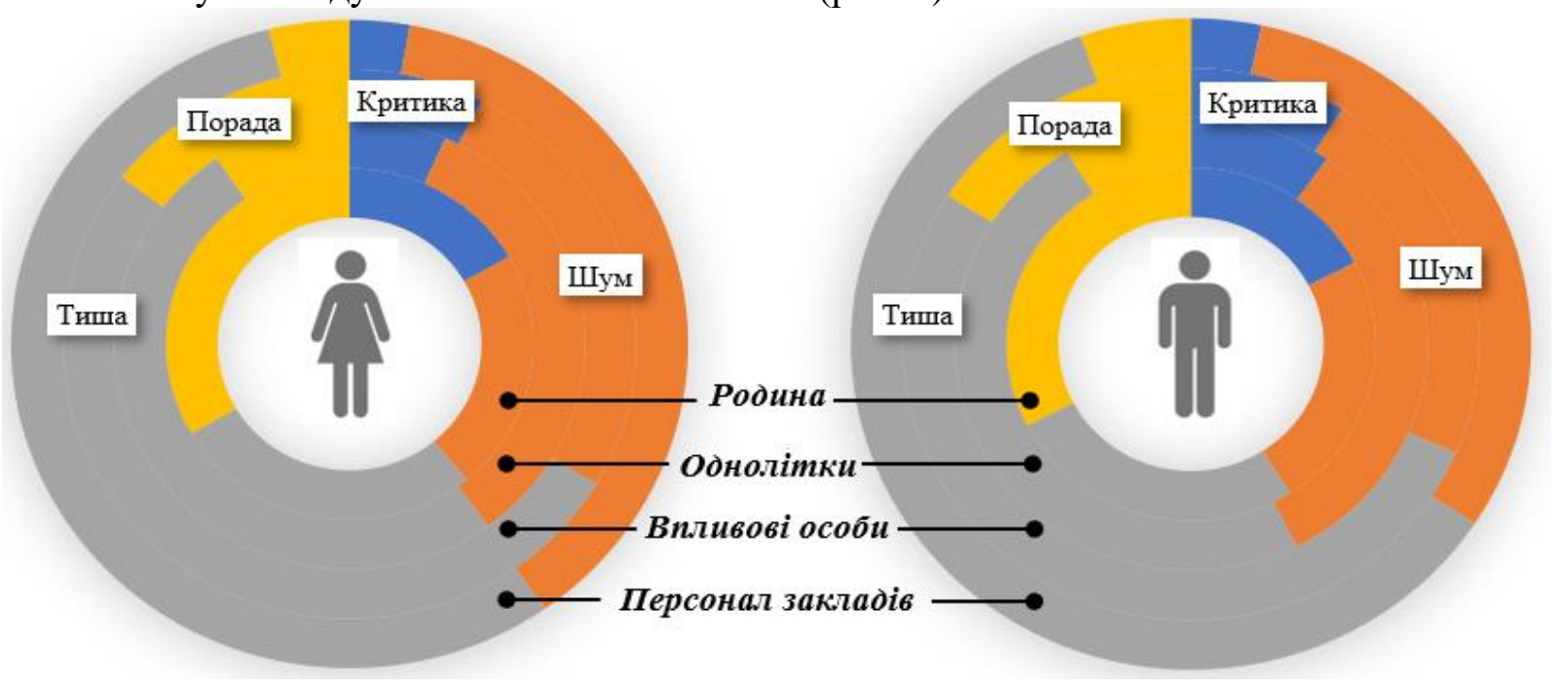

Рисунок 2 - Якість референтного простору дитини шкільного віку у питаннях безпеки харчування Джерело: розроблено автором

У дітей обох статей спостерігається значна частка «тиші» й незначна частка «порад» при контакті із соціальним оточенням. Даний факт є свідченням того, що тема безпеки харчування не є розповсюдженим та популярним предметом обговорення дітьми зі всіма групами людей з їх оточення. У більшості випадків для дітей обох статей джерелом важливих порад є батьки та інші члени родини. Порівняно з іншими групами соціального оточення саме у родині діти отримують більше порад, але й більше критики на адресу власних харчових звичок та уподобань. На непопулярність обговорення проблематики харчування також вказують відповіді дітей щодо частоти спілкування на тему безпеки харчування та правильного харчування (табл. $5)$.

За результатами опитування визначено, що для кожної другої дитини тема правильного харчування не $\epsilon$ предметом спілкування із такими впливовими особами, як шкільні вчителі, тренери секцій та керівники гуртків. Однак, вразі обговорення, діти від цієї категорії осіб частіше отримують важливі та корисні поради, аніж чують критику.

У рідких випадках діти обговорюють питання харчування, складу продуктів, їх харчової цінності із персоналом кафе, шкільної їдальні та інших закладів харчування. Лише одиниці дітей шкільного віку запитують персонал супермаркетів та ринків щодо користі, шкоди, складу та свіжості тих чи інших продуктів харчування, що робить їх більш вразливими з огляду на комерційні цілі недобросовісних суб'єктів господарювання.

Висновки та перспективи подальших досліджень. Відсутність методики визначення впливу соціального оточення на споживчий вибір ускладнює формування маркетингових підходів до здійснення керованого впливу на споживчу поведінку дітей на ринку продуктів харчування.

Запропонована у статті методика аналізу впливу соціального оточення на поведінку споживача передбачає низку етапів: 
Частота спілкування дітей шкільного віку із соціальним оточенням на тему безпеки харчування, \%

\begin{tabular}{|c|c|c|c|c|c|c|c|c|}
\hline \multirow[b]{2}{*}{ Референтна група } & \multicolumn{2}{|c|}{ Ніколи } & \multicolumn{2}{|c|}{ Інколи } & \multicolumn{2}{|c|}{ Часто } & \multicolumn{2}{|c|}{ Постійно } \\
\hline & 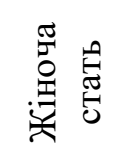 & 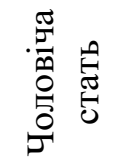 & 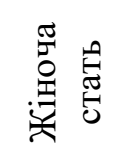 & 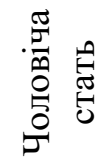 & 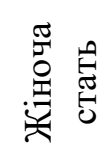 & 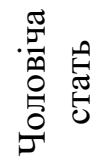 & 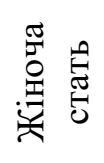 & 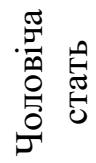 \\
\hline Родина & 20,57 & 19,05 & 43,06 & 44,52 & 28,23 & 28,33 & 8,13 & 8,10 \\
\hline Впливові особи & 45,93 & 47,86 & 37,32 & 34,05 & 12,92 & 14,76 & 3,83 & 3,33 \\
\hline Однолітки & 34,93 & 48,10 & 48,56 & 44,29 & 14,59 & 6,43 & 1,91 & 1,19 \\
\hline Персонал закладів & 84,21 & 79,52 & 12,44 & 17,62 & 2,39 & 2,38 & 0,96 & 0,48 \\
\hline
\end{tabular}

Джерело: розроблено автором

1) визначення чинників соціального оточення;

2) здійснення споживачами оцінки ступеня важливості даних чинників;

3) розрахунок узагальнюючого показника значущості чинника;

4) визначення інтенсивності впливу груп соціального оточення, як ваги сприйняття респондентами значення впливу цієї групи, та ранжування отриманих показників за зменшенням рівня значущості;

5) оцінка направленості впливу соціального оточення через аналіз якості референтного простору на основі розробленої моделі CNSA («Критика-шум-тишапорада»);

6) на основі аналізу інтенсивності та направленості впливу різних груп соціального оточення можливо сформувати кільцеву діаграму, яка відтворює референтний простір респондента, кільця якої розташовують за принципом поступового віддалення від центру фігури за ступенем зменшення значущості впливу (наближені до центру кола відображають вплив найбільш значущої групи соціального оточення, наступні кола розташовуються за зменшенням їх значущості);

7) відсотковий розподіл висловлювань окремих груп соціального оточення за 4 типами впливу відповідно до моделі CNSA дозволить оцінити якість соціального оточення 3 конкретних питань та визначити наявність чи відсутність ідеальної референтної групи.

На основі запропонованої методики здійснено аналіз впливу соціального оточення на споживчу поведінку дітей шкіль- ного віку. Отримані дані характеризують референтний простір дітей з огляду на обговорення тематики системи харчування дітей шкільного віку. Доведено, що відсутня ідеальна референтна група дітей шкільного віку. Наявна відмінність якості референтного простору дітей шкільного віку жіночої та чоловічої статі. Доведено, що тема безпеки харчування не $є$ розповсюдженою та популярною темою для обговорення дітьми зі всіма групами соціального оточення. Типова українська дитина шкільного віку час від часу обговорюють тему правильного харчування у родинному колі та 3 однолітками й друзями. Для кожної другої дитини тема правильного харчування не $є$ предметом спілкування із такими впливовими особами, як шкільні вчителі, тренери секцій та керівники гуртків. Діти ніколи не обговорюють питання харчування із персоналом кафе, шкільної їдальні та інших закладів харчування, не перепитують у персоналу супермаркетів та на ринках щодо користі або шкоди тих чи інших продуктів харчування. Отримані результати можуть бути використані суб'єктами господарювання у процесі формування маркетингової стратегії на ринку продуктів харчування для дітей.

Подальших досліджень потребує визначення впливу інших чинників на поведінку споживача та визначення особливостей процесу прийняття рішення дітьми шкільного віку щодо придбання та споживання продуктів харчування, а також визначення зміни сприйняття впливу соціального оточення у проуесі до- 
рослішання дитини та споживчої соціалізації.

\section{Література}

1. Коноваленко А. Соціальнодемографічні чинники розвитку ринку продуктів та послуг харчування дітей. Науковий вісник Полісся. 2019. 2 (18). С. 42-49. doi: 10.25140/2410-9576-2019-2(18)-42-49

2. Маркетингові дослідження інноваціий та підприємницькі ризики / М. А. Окландер, Т. О. Окландер, I. А. Педько, О.І. Яшкіна. ; за ред. М. А. Окландер. Одеса : Астропринт, 2017. 284 c.

3. Darya G. Legeza, Thomas A. Brunner, Yukilay K. Kerimova, Tatyana V. Kulish, Anastasia S. Konovalenko (2019), "A model of consumer buying behavior in relation to ecointelligent products in catering", Innovative Marketing, Volume 15, Issue 1, pp. 54-65, http://dx.doi.org/10.21511/im.15(1).2019.05

4. Прокопенко О.В., Троян М.Ю. Поведінка споживачів: навчальний посібник. Київ: Центр учбової літератури, 2008. 176 с.

5. Кочкіна Н. Дослідження мотивації підліткової аудиторії українських споживачів. Маркетинг в Україні. 2013. № 1. С. 34-43. URL: http://nbuv.gov.ua/UJRN/Mvu_2013_1_7.

6. Теорія споживчої поведінки в трактуванні маркетингу: [монографія] /

Стаття надійшла

до редакції : 05.11.2020 p.
Нєізвєстна О. В., Скринько Н. В. ДонНУЕТ, 2016. $216 \mathrm{c}$

\section{References}

1. Konovalenko, A. (2019). Sociodemographic factors of development of the market of products and services of children's nutrition. Scientific Bulletien of Polissia. 2 (18), 4249. doi: 10.25140/2410-9576-2019-2(18)-42-49

2. Oklander, M.A. Oklander, T.O. and Pedko, I.A. (2017). Marketing research of innovations and business risks. Astroprynt, Odessa, 284.

3. Darya G. Legeza, Thomas A. Brunner, Yukilay K. Kerimova, Tatyana V. Kulish, Anastasia S. Konovalenko (2019), "A model of consumer buying behavior in relation to ecointelligent products in catering", Innovative Marketing, Volume 15, Issue 1, pp. 54-65, http://dx.doi.org/10.21511/im.15(1).2019.05

4. Prokopenko, O.V., Troyan, M.Yu. (2008). Consumer behavior, Center uchbovoï literaturi, Kyiv, Ukraine, 176.

5. Kochkina, N. (2013). A study of the motivation of the adolescent audience of Ukrainian consumers. Marketing in Ukraine. № 1, 3443.

URL:

http://nbuv.gov.ua/UJRN/Mvu_2013_1_7.

6. Neizvestnaia, O., Skrinko, N. (2016). The theory of consumer behavior in the interpretation of marketing. DonNUET, 216.

Стаття прийнята

до друку: 28.12.2020 p.

Бібліографічний опис для цитування :

Коноваленко А. С. Аналіз впливу соціального оточення на модель поведінки споживача / А. С. Коноваленко // Часопис економічних реформ. - 2020. - № 4 (40). - С. $76-84$. 